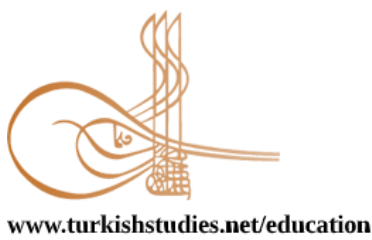

Turkish Studies - Educational Sciences

Research Article / Araştırma Makalesi

\title{
Yabancılara Türkçe Öğretiminde Dijital Hikâye Anlatımının Yaratıcı Yazma Becerisine ve Yazma Öz Yeterliğine Etkisi*
}

\author{
The Effect of Digital Storytelling on Creative Writing Skills and Writing Self-Efficacy in Teaching \\ Turkish to Foreigners
}

\author{
Erkan Aydın* - Fatih Mehmet Ciğerci*
}

\begin{abstract}
The aim of the research is to examine whether digital storytelling has an effect on creative writing skills and writing self-efficacy of students learning Turkish as a foreign language. Since the study has quantitative and qualitative data, the mixed method was used. Since both quantitative and qualitative data are analyzed and interpreted in the research, triangulation design is used from mixed method patterns. In the quantitative dimension of the research, the model with "pre-test and post-test control group" was used; The qualitative phenomenological design was used. The study group of the research consists of students at B1 level who study at TOMER within Harran University. In the research, 2 classes at B1 level were divided into experimental and control groups with unbiased assignment. The study was carried out with a total of 40 students, 21 from the experimental group and 19 from the control group. The ten-week practice lasted from level B1 to the end of level B2. In the pre-test and post-test of the research, the quantitative data obtained from students' composition writing studies were collected with the Written Expression Grading Key developed by Büyükikiz (2011) and the Writing Self-Efficacy Scale developed by Büyükikiz (2011). Qualitative data were collected at the end of the research with the "Semi-Structured Interview Form" developed by the researcher to obtain the students' opinions. In the analysis of quantitative data, Mann-Whitney U test was used to evaluate students' composition writing studies, and t-test was used to evaluate writing self-efficacy. In the analysis of qualitative data, content analysis was used. According to the quantitative results of the research; The students' creative writing skills and writing self-efficacy post-test scores revealed a significant difference in favor of the experimental group students. This revealed that writing lessons based on digital storytelling are more effective and efficient than writing lessons taught with the current program. According to the qualitative results of the research, students stated that the lessons taught with digital stories improve their writing skills; stated that they learned the rules of spelling and punctuation in lessons and that they have a better command of grammar rules. In addition, students think that their vocabulary has increased in this process.
\end{abstract}

\footnotetext{
* Bu araştırma "Yabancılara Türkçe Öğretiminde Dijital Hikâye Anlatımının Yaratıcı Yazma Becerisine Etkisi" adlı doktora tezinden üretilmiştir.

* Dr., Milli Eğitim Bakanlığı

Dr. Ministry of Education

ORCID 0000-0002-6452-6058

erkanaydin02@gmail.com

** Dr. Öğr. Üyesi, Harran Üniversitesi, Eğitim Fakültesi, Temel Eğitim Bölümü

Asst. Prof. Dr., Harran University, Faculty of Education, Basic Education Department

ORCID 0000-0002-4175-7048

fatihmehmetcigerci@hotmail.com
}

Cite as/ Atıf: Aydın, E. \& Ciğerci, F. M. (2020). Yabancılara türkçe öğretiminde dijital hikâye anlatımının yaratıcı yazma becerisine ve yazma öz yeterliğine etkisi. Turkish Studies, 15(4), 2425-2442. https://dx.doi.org/10.7827/TurkishStudies.41552

Received/Geliş: 30 January/Ocak 2020

Accepted/Kabul: 29 July/Temmuz 2020

Copyright $\mathbb{C}$ MDE, Turkey

Checked by plagiarism software

Published/Yayın: 30 August/Ağustos 2020

CC BY-NC 4.0 
Structured Abstract: Introduction Writing education has an important place for both the mother tongue and the target language. Planning emotions and thoughts effectively and expressing them in accordance with the rules of the language forms the basis of writing skills (İnal, 2014: 363). In teaching Turkish as the target language, rather than an individual's knowing the rules of the language and words, it is aimed for the individual to be able to communicate verbally and in writing by using these rules and words (İscan, 2011: 30). It has been stated in the related literature that students experience various writing skills in teaching Turkish to foreigners. Açık (2008) stated that more than 40\% of the students had problems in writing. Arslan and Kılıç (2015) stated that students who learn Turkish as a foreign language have difficulties in making a Turkish sentence while writing because they think in their native language and cannot create long texts due to the limited vocabulary. Since students who learn Turkish as a foreign language perceive writing as a difficult task, they are adversely affected by emotional factors such as writing self-efficacy and writing anxiety (Melanlığlu \& Atalay, 2016). In this context, it is seen that students experience different problems in writing skills. Therefore, more effective ways, methods and tools should be used in foreign language teaching in order to eliminate students' writing difficulties and increase their writing self-efficacy (Tok, 2013: 249). In foreign language teaching, computer and digital media are used with various learning tools. With the introduction of technological tools into the classroom environment, the traditional story type has been integrated into the digital environment. Now, storytellers can tell their stories with many web tools like blogs, websites, forums (Turgut \& K1şla, 2015: 112). Digital stories are used to convey or teach information depending on a subject. According to Frazel (2009), the digital story puts the student in an active process and provides the student with a fun classroom environment. According to various researches, digital storytelling makes learning environment efficient and provides permanent learning (Ciğerci \& Gültekin, 2017; Jakes \& Brennan, 2005; Lambert, 2006; Robin, 2008).

\section{Method}

The mixed method was used in this research, which aims to examine the effect of digital storytelling method on the creative writing skills of students who learn Turkish as a foreign language. The study was carried out with a total of 40 students, aged between 18 and 26.21 of the participants are in the experimental group and 19 in the control group.

\section{Findings}

According to the pretest results at the beginning of the application, no significant difference was observed according to experimental and control group's scores on written expression rubric $[\mathrm{U}=147,(\mathrm{p}=$ $.159, \mathrm{p}<0.05)]$ and the writing self-efficacy scale $\left.\left[t_{(38)}=1.084, p=.285, p<0.05\right)\right]$. According to the postet results, a meaningful difference was obtained from written expression rubric $[\mathrm{U}=63.50,(p=.000, p<0.05)]$ and the writing self-efficacy scale $\left[t_{(38)}=2.042,(p=.048, p<0.05)\right]$ in favor of the experimental group.

\section{Conclusion and Discussion}

According to the quantitative results of the research, it has been revealed that digital storytelling is more effective than the current program in developing creative writing skills and writing self-efficacy of students who learn Turkish in a foreign language. The research findings made with studies to improve the writing skills and writing self-efficacy of students who learn Turkish as a foreign language are similar. Accordingly, Turkben (2019) concluded that creative writing practices improve students' writing skills and writing self-efficacy in their study with B2 students who learn Turkish as a foreign language. In his study, Chef (2019) found that B2 level students' writing skills improved in teaching Turkish as a foreign language by using story writing studies. In the study of Yildırım (2018), it was concluded that the post-test scores obtained from writing skills as a result of writing development file application of B2 level students who learn Turkish as a foreign language are significant in favor of the experimental group. In foreign language teaching, the findings of the studies conducted to improve the writing skills with digital story applications match the findings of the study. Accordingly, when the studies investigating the effect of digital storytelling on writing skill are examined, the following results are determined. Kim (2018) stated that EFL undergraduate students' participation in digital storytelling activities improved their writing skills. Balaman Uçar (2016) found that undergraduate students who learn English as a foreign language are successful in the writing skills and writing self-efficacy of the experimental group students who do integrated writing based on digital stories. Abdel-hack and Helwa (2014) stated that the post-test scores of the experimental group students using digital storytelling from the narrative writing skill were significant compared to the control group in their study on EFL undergraduate students. Sepp and Bandi-Rao (2015) found that students who use digital storytelling improve 
their writing skills in their study on ESL college students. Kim (2018) pointed out that digital storytelling is an effective tool in improving pre-service teachers' writing skills in foreign language and changing their perceptions on this subject. According to the qualitative results of the research, students stated that their composition writing skills improved with digital storytelling and that they learned the rules of spelling and punctuation while writing the script of the digital story. At the same time, the students stated that they had problems with punctuation and spelling rules and that they had improved their writing skills after the application, they learned more words. The results obtained from the studies examining the contribution of digital stories to writing skills and the results obtained from this research support each other. Accordingly, Balaman Uçar (2016) state that students learning foreign languages improve their subtitling skills, including grammar, spelling or vocabulary through digital story studies. In Kim's (2018) study with EFL students, students state that digital stories provide the opportunity to create scenarios and write stories, improve their writing skills, increase awareness of foreign language learning, improve the ability to use words correctly and improve their writing.

Keywords: Turkish as a Foreign Language, Creative Writing Skill, Writing Self-Efficacy, Digital Storytelling

Öz: Araştırmanın amacı, dijital hikâye anlatımının yabancı dil olarak Türkçe öğrenen öğrencilerin yaratıcı yazma becerisi ve yazma öz yeterliği üzerinde etkili olup olmadığını incelemektir. Araştırmada nicel ve nitel veriler bulunduğu için karma yöntem kullanılmıştır. Araştırmada hem nicel hem nitel veriler, birlikte analiz edilip yorumlandığından karma yöntem desenlerinden birleştirme/çeşitleme deseninden yararlanılmıştır. Araştırmanın nicel boyutunda, "ön-test ve son-test kontrol gruplu" model kullanılmış; nitel boyutunda ise olgubilim (fenomenoloji) deseni kullanılmıştır. Araştırmanın çalışma grubunu Harran Üniversitesinin bünyesindeki TÖMER'de öğrenim gören B1 seviyesindeki öğrenciler oluşturmaktadır. Araştırmada, B1 seviyesinde yer alan 2 sınıf, yansız atamayla deney ve kontrol grubuna ayrılmıştır. Araştırma, deney grubundan 21, kontrol grubundan ise 19 öğrenci olmak üzere toplam 40 öğrenci ile gerçekleştirilmiş̧tir. On hafta süren uygulama, B1 seviyesinden başlayıp B2 seviyesinin sonuna kadar sürmüştür. Araştırmanın ön-test ve sontestinde öğrencilerin kompozisyon yazma çalışmalarından elde edilen nicel veriler, Büyükikiz (2011) tarafından geliştirilen "Yazılı Anlatım Dereceli Puanlama Anahtarı" ve yine Büyükikiz (2011) tarafindan geliştirilen "Yazma Öz Yeterlik Ölçeği” ile toplanmıştır. Nitel veriler ise araştırmanın sonunda, öğrencilerin görüşlerini almak için araştırmacı tarafından geliş̧tirilen "Yarı Yapılandırılmış Görüşme Formu" ile toplanmıştır. Nicel verilerin analizinde, öğrencilerin kompozisyon yazma çalışmalarını değerlendirmek için Mann-Whitney U testi, yazma öz yeterliğini değerlendirmek için t-testi kullanılmışıır. Nitel verilerin analizinde ise içerik analizinden yararlanılmıştır. Araştırmanın nicel sonuçlarına göre; öğrencilerinin yaratıcı yazma becerileri ve yazma öz yeterliği son-test puanlarının deney grubu öğrencilerinin lehine anlamlı bir farklılık olduğu ortaya çıkmıştır. Bu durum, dijital hikâye anlatımına dayalı işlenen yazma derslerinin mevcut program ile işlenen yazma derslerine göre daha fazla etkili ve verimli olduğu sonucunu ortaya koymuştur. Araş̧ırmanın nitel sonuçlarına göre ise öğrenciler, dijital hikayelerle işlenen derslerin yazma becerilerini geliştirdiğini; derslerde yazım, noktalama kurallarını ögrendiklerini ve dil bilgisi kurallarına daha iyi hâkim olduklarını ifade etmiştir. Ayrıca öğrenciler, bu süreçte kelime hazinelerinin arttığını da düşünmektedir.

Anahtar Kelimeler: Yabancı Dil Olarak Türkçe, Yaratıcı Yazma Becerisi, Yazma Öz Yeterlik, Dijital Hikâye Anlatımı

\section{Giriş}

Yazma, herhangi bir konu hakkında düşüncelerin, duyguların, hayallerin, zihinde oluşturulan bilgilerin, özgün fikirlerin, belirli bir düzen ve yapı içinde dile ait sembollerle kodlanarak yazıya aktarılmasıdır (Coşkun, 2014; Göçer, 2010; Güneş, 2014; Karadağ \& Maden, 2014; Sever, 2014). Yazma eylemi, kelime ve cümleyi anlam bütünlüğüne, dilbilgisi, yazım ve noktalama kurallarına uygun şekilde ve belirli bir düzende yapılması gereken uzun süreçli bir eylemdir. Zihinsel, üst bilişsel, duyusal ve birçok süreci içinde barındıran yazma eylemi; okuma, düşünme ve düzgün ifade etme becerilerini de içerdiğinden ötürü uygulaması zor bir eylem olarak görülebilir (Ungan, 2007: 462). 
Yazma eylemi; öncelikle zihinsel bir ön hazırlık süreciyle başlar, daha sonra yazar tarafından yazma amacı belirlenerek uygun bir yöntem seçilir. Bu süreç, konunun sınırlandırılması ve anlatılanların yazma kurallarına uygun biçimde yazılmasıyla devam eder. Yazısının taslağını oluşturan yazar, yazısını düzenleyerek ve geliştirerek yeniden biçimlendirir. Son olarak da ortaya çıkan yazı yayınlanma sürecine girer.

Yazma eğitimi, bireyin kendi yaşantısı sonucunda edindiği bilgi ve birikimi, hayal gücü ve imgeleme yoluyla yoğurarak, kâğıda aktarmasından daha ziyade karmaşık anlam ifade eder (Genç, 2017: 31-32). Yazma eğitimi gerek ana dil ve gerekse hedef dil için çok önemli bir yer oluşturur. Çünkü bireyin duygu ve düşüncelerini bir plan dahilinde ve etkili bir şekilde anlatması için yazma eğitimi önemlidir. Türkçenin hedef dil/yabancı dil olarak öğretiminde, bireyin dile ait sözcükleri ve dil kurallarını bilmesinden daha çok, bu sözcük ve yapıları kullanarak o dilde sözlü ya da yazılı iletişim kurabilmesi amaçlanır (İşcan, 2011: 30).

Yazma; bireyin etkili iletişim kurmasını, estetik ve edebî anlayışını, eleştirel düşünmesini, özgünlüğünü, yaratıcılığını ve buna bağlı olarak birçok becerisini geliştirmeye olanak sağlar. Yabancılara Türkçe öğretiminde yazma becerisi, çeşitli hedef ve kazanımların elde edilmesine yardımcı olur. Bu bakımdan yabancılara Türkçe öğretiminde yazma becerisi:

- Öğrenme sürecini kontrol etmeye,

- Öğrenme sürecini takip etmeye,

- Öğrencilerin seviyelerini belirlemeye,

- Dil yanlışlarının görülmesine,

- Noktalama işaretlerinin öğretilmesine,

- Öğretilen yapıların veya kelimelerin pekiştirilmesine,

- Öğrencilerin dil yetilerinin gelişmesine,

- Öğrencilerin yetilerini (competence) performansa dönüştürmelerine,

- Öğrencilerin yaratıcı düşünmelerine,

- Diğer becerilerin daha iyi öğrenilmesine,

- Konuların öğrenildikten sonra kısa süreli bellekte uzun süreli belleğe aktarılmasına yardımcı olur (Çakır, 2010: 167-168).

Türkçeyi yabancı dil olarak öğrenen öğrencilerin yazma süreçlerinde zorluklar yaşadığı, yazmaya karşı ilgisiz ve isteksiz oldukları düşünülmektedir. Öğrencilerin yazma becerisinde, farklı sorunlar yaşaması ve yazma motivasyonlarının düşük olması, bu beceri üzerinde daha fazla durulmasını gerekli kılmaktadır (Tok, 2013: 249). Bu bağlamda yabancılara Türkçe öğretiminde, öğrencilerin yazma becerisiyle ilgili farklı sorunlar yaşadığı konuyla ilgili çalışmalarda tespit edilmiştir. Buna göre, Açık (2008) yabancı uyruklu öğrencilerin \% 40 'tan fazlasının yazma sürecinde sorun yaşadığını; Arslan ve Klıcıc (2015) öğrencilerin kendi ana dili mantığıyla düşünmesinden ötürü yazı yazarken düzgün cümle kurmakta zorlandıklarını, kelime hazinelerinin yetersiz olduğu için de uzun metinler oluşturamadığını; Genç İlter (2014) ise öğrencilerin hazırbuluşluklarının yeterli olmayışı, öğretmenlerin yanlış uygulamaları, uygun araç-gereçlerin kullanılmaması durumunda yazma süreçlerinin olumsuz etkilenebileceğini ifade etmiştir. Türkçeyi sonradan öğrenen öğrenciler, yazmayı zor bir görev olarak düşündüklerinden dolayı yazma kaygısı, yazma öz yeterliği vb. birçok duygusal unsurdan olumsuz etkilenmektedir (Melanlığlu \& Atalay, 2016). Yabanc1 dil olarak Türkçe öğretiminde, öğrencilerin yazma becerisinde çeşitli problemlerle karşılaştı̆g 1 görülmektedir. $\mathrm{Bu}$ bakımdan öğrencilerin yazma sorunlarının giderilmesi ve yazma öz yeterliklerinin arttırılması amacıyla daha farklı yol, yöntem ve araçların denenmesinin gerekli olduğu görülmektedir.

Yabancılara Türkçe öğretmek amacıyla drama, benzetim, gösteri, ikili veya grup çalışmaları, eğitsel oyunlar, dil bilgisi oyunları ve görsel işitsel araçlarla öğretim gibi çeşitli teknikler öne çıkmaktadır. Bu teknikler, temel olarak yabancı dil öğretiminin kolay ve etkili olmasını sağlamak için oluşturulmuştur. Gerek Millî Eğitim Bakanlığı (MEB) bünyesinde yer alan Hayat Boyu 
Öğrenme Genel Müdürlüğü tarafindan Suriyeli Çocukların Türk Eğitim Sistemine Entegrasyonunun Desteklenmesi Projesi (PICTES) kapsamında yaygın eğitim amacıyla hazırlanan yabancılar için Türkçe öğretim programlarında gerekse Türkiye Maarif Vakfı, Türkçenin yabancı dil olarak öğretiminin uluslararası standartlara uygun olarak planlı ve programlı bir şekilde yürütülmesi için hazırlanan Yabancı Dil Olarak Türkçe Öğretim Programında bu öğretim yöntemlerine yer verilmiştir (Kaya \& Kardaş, 2019a: 96; Kaya \& Kardaş, 2019b: 125-126). Bu bağlamda, yabanc1lar için Türkçe öğretim programları hazırlanırken Avrupa Ortak Başvuru Metni'nin usul ve esasları dikkate alınması gerekmektedir. Avrupa Ortak Başvuru Metni'nin ilkeleri, Avrupa ülkeleri arasında dil ve kültür çeşitliliğinin korunması, ortak anlayış ve iş birliğinin güçlendirilmesi, farklı ana dillere sahip bireyler arasında iletişimin geliştirilmesi, modern dil öğretimini benimseyen bir programın oluşturulması esaslarına dayanır. Bu amaçla Avrupa Konseyi üye ülkeleri, modern dil öğreniminde ve çoklu medya kullanımında, ulusal ve uluslararası iş birliğini arttırmayı, bilgi teknolojilerini kullanarak etkin bir Avrupa dil öğrenme ve öğretme sistemini oluşturmayı gerçekleştirmek istemiştir (MEB, 2009: 1). Yani çağın gereklilikleri, modern dil öğretimi, ülkenin misyon ve vizyonu için bilgi teknolojisinin daha etkin kullanılması; bunun için de Avrupa Ortak Başvuru Metni'nde yer alan amaçlar doğrultusunda, yabancılara Türkçe öğretim programı hazırlanması, dil öğretimini uluslararası standartlara taşınmasını sağlayacaktır.

Dil öğretiminde görsel ve işitsel araçların önemi, teknolojik gelişmelere bağlı olarak gitgide artmaktadır. Görsel ve işitsel araçlar, dil öğrenen öğrencilerin dersi anlamasını, derslere aktif katılmasını, çok fazla uyarıcıyla karşı karşıya kalmasını sağlamaktadır. Yani öğrencilerin farklı konuları daha kolay kavramasında ve motivelerinin artmasında görsel ve işitsel araçların önemi büyüktür (Arslan \& Adem, 2010: 85). Bu bakımdan öğrenme ortamlarında görsel ve işitsel araçlara daha fazla yer verilmesi, dil öğretimini ve farklı becerilerin öğrenimini istenilen seviyeye getirmenin etkili yollarından biri olabilir.

Yabancı dil öğretiminde, dijital ve teknolojik araçlar önemli bir yer teşkil etmektedir. Son zamanlarda gerçekleşen dijital dönüşümle beraber eğitim ortamlarında kullanılan bilgisayarlar, tabletler ve telefonlar sayesinde işlenen dersler daha çok verimli ve etkili hâle gelmektedir. Teknolojik araçların öğrenme ortamlarında kullanılmasıyla beraber geleneksel hikâye türü dijital ortamlara entegre edilmiştir. Bilhassa bilgisayar teknolojisinin yaygınlaşmasıyla beraber geleneksel hikâyeler elektronik ortamda yazılıp, saklanmaya ve paylaşılmaya başlanmış, bu bakımdan İnternet'in kullanılması ile hikâyeler sanal bir boyut kazanmıştır (Turgut \& Kışla, 2015: 112). Bu bağlamda, teknolojik bir eğitim aracı olan dijital hikâyeler, duygu ve düşünceleri dile getirmek, bilgi aktarmak veya bilgiyi öğretmek için kullanılmaktadır. Dijital hikâye anlatımı ses, resim, efekt, müzik, video gibi çoklu medya araçlarının kullanımıyla yapılan bir yöntemdir. Dijital hikâyeler oluşturulurken öncelikle öğrenciler, belirledikleri konuyla ilgili senaryolar yazar, yazdıklarını düzeltir ve paylaşır. Bu bakımdan dijital hikâye anlatımının yazma becerisine doğrudan katkısı olduğu söylenebilir. Frazel'e (2009) göre dijital hikâye anlatımı, öğrenciyi daha aktif hale getirmekte ve eğlenceli bir öğrenme ortamına sokmaktadır. Dijital hikâye anlatımı, teknolojik olanaklarla birlikte okul ile toplum arasında önemli ve birleştirici bir rol üstlenmektedir. Dijital hikâye anlatımının öğrenme ortamını etkili ve verimli hâle getirdiği, öğrencilerde kalıcı öğrenmeler sağladığı, birçok farklı becerinin gelişimine katkısının olduğu birçok araştırmanın sonucunda ortaya konulmuştur (Ciğerci \& Gültekin, 2017; Jakes \& Brennan, 2005; Lambert, 2006; Robin, 2008). Öğrencilerin dijital hikâyeleri kullanarak duygularını, düşüncelerini, hayallerini açık ve etkin bir biçimde yazıya aktardığı bilinmektedir (Diaw, 2009; Foley, 2013; Green, 2011; Jakes \& Brennan, 2005; Kulla-Abbott, 2006; Speaker, 2010; Xu vd., 2011).

Dijital hikâye oluştururken önemli bazı temel öğeler bulunmaktadır. Genellikle grup ortamında kullanılan dijital hikâye anlatımı; işbirlikçi, gerçekçi ve eğlenceli bir yapıya sahiptir. Bu süreçte geliştirme, bağlanma, öğrenme ve yetiştirme gibi kolektif yapılar vardır (Ohler, 2006). Dijital 
hikâye anlatımının birbiriyle ilişkili yedi temel ögesi bulunmaktadır (Ohler, 2006; Robin, 2006). Bu temel ögeler, bireye dijital hikâyelerde hangi unsurların önemli olduğunu ve dijital hikâye hazırlarken nelere dikkat edilmesi gerektiğini anlatır. Birbirini tamamlayan ve dijital hikâyenin hazırlanması için gerekli bu yedi öge Şekil 1'de gösterilmiştir.

\begin{tabular}{|c|c|}
\hline \multirow{7}{*}{$\begin{array}{l}\text { Dijital Hikâyenin } \\
\text { Ögeleri }\end{array}$} & Bakış açısı (Point of view): Yazarın belirli bir bakış açısına sahip olması \\
\hline & $\begin{array}{l}\text { İlgi/Dikkat çekici soru (Dramatic question): Hikâyenin başından } \\
\text { sonuna kadar dikkati ve ilgiyi canlı tutucak sorunun sorulması. }\end{array}$ \\
\hline & $\begin{array}{l}\text { İyi bir seslendirme (The gift of your voice): Hikâyenin anlaşılırlığını } \\
\text { sağlayacak iyi bir seslendirmenin seçilmesi. }\end{array}$ \\
\hline & $\begin{array}{l}\text { Duygusal içerik (Emotional content): Kişisel ve güçlü bir biçimde } \\
\text { konuşulacak ciddi konuların seçilmesi. }\end{array}$ \\
\hline & $\begin{array}{l}\text { Müziğin kullanımı (Soundtrack): Hikâyeyi destekleyecek müzik veya } \\
\text { başka seslerin kullanılması. }\end{array}$ \\
\hline & $\begin{array}{l}\text { Ekonomi (Ekonomy): Hikâyeyi oluşturan unsurlara aşırı yükleme } \\
\text { yapmadan yeterli ve uygun içerik kullanılması. }\end{array}$ \\
\hline & Hız (Pacing): Hikâyenin hızının ayarlanması. \\
\hline
\end{tabular}

Şekil 1. Dijital Hikâye İçin Bulunması Gereken Ögeler

Dijital hikâye hazırlama, çeşitli aşamaların kullanılmasıyla yapılır. Bu süreçte yapılacak özenli bir çalışmayla hem teknik ve hem de pedagojik açıdan kaliteli ve verimli ürünler ortaya çıkacaktır (Yılmaz vd., 2017; 1625).

Barret (2009) dijital hikâye oluşturmanın beş farklı aşamada gerçekleştiğini ifade eder. $\mathrm{Bu}$ aşamalar, Şekil 2'de şu şekilde gösterilmiştir:

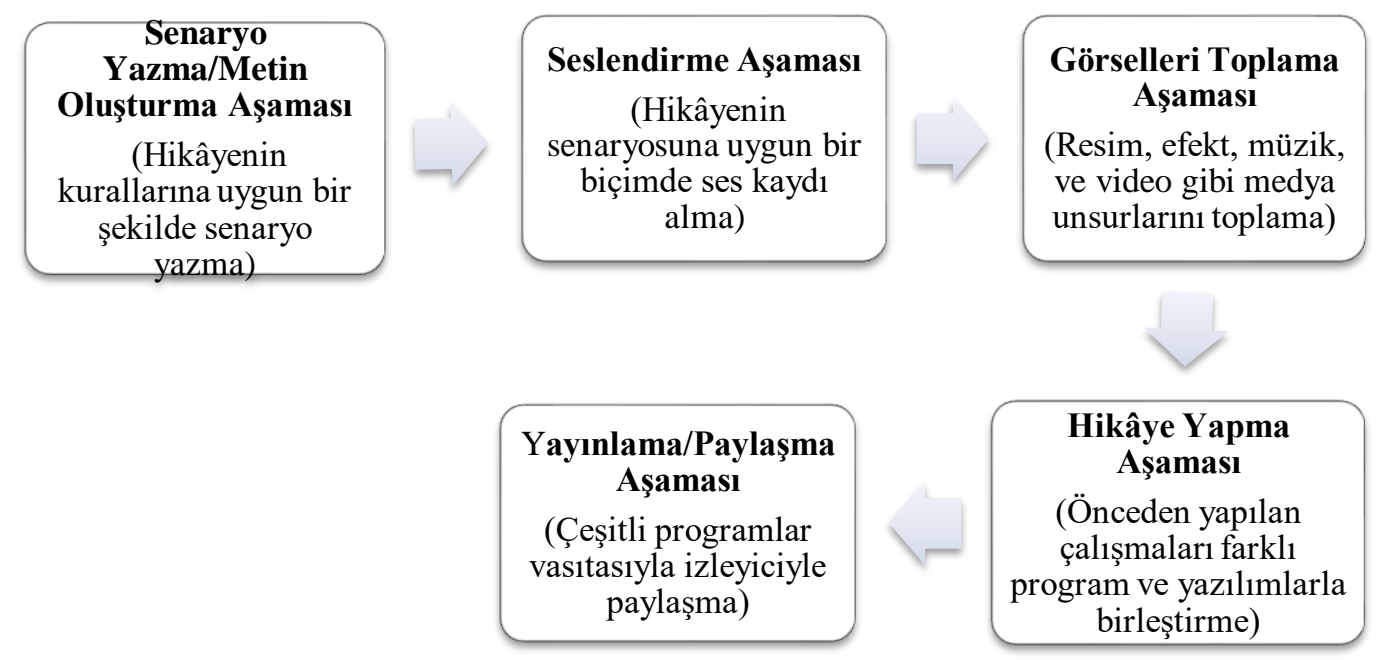

Şekil 2. Dijital Hikâye Oluşturma Aşamaları (Barret, 2009)

Yabancı dil öğretiminde, öğrencilerin temel becerileri kazandırmasını sağlamak ve dili pratik bir şekilde kullanmasını kolaylaştırmak için birçok farklı yol ve yöntem denenmektedir. Farklı yöntemlerin ve araçların geliştirilmesi, öğrencilerin dil öğrenimine ve temel dil becerilerinin gelişimine katkısı olacağı düşünülebilir. Bu bakımdan araştırmanın amacı, yabancı dil olarak Türkçe öğrenen öğrencilerin yazma becerilerini ve yazma öz yeterliklerinin gelişmesinde dijital hikâye 
anlatımının etkili olup olmadığını incelemektir. Bu genel amaç doğrultusunda aşağıdaki sorulara cevap aranmıştır:

- Deney grubu ile kontrol grubunun "Yazılı Anlatım Dereceli Puanlama Anahtar1 (Rubrik)"ndan aldıkları ön-test puanları arasında anlamlı bir farklılık var mıdır?

- Deney grubu ile kontrol grubunun "Yazılı Anlatım Dereceli Puanlama Anahtarı (Rubrik)"ndan aldıkları son-test puanları arasında anlamlı bir farklılık var mıdır?

- Deney grubu ile kontrol grubunun "Yazma Öz Yeterlik Ölçeği”nden aldıkları ön-test puanları arasında anlamlı bir farklılık var midır?

- Deney grubu ile kontrol grubunun "Yazma Öz Yeterlik Ölçeği”nden aldıkları son-test puanları arasında anlamlı bir farklılık var midır?

- Deney grubunun dijital hikâyelere dayalı yaratıcı yazma süreçleriyle ilgili görüşleri nelerdir?

\section{Yöntem}

\section{Araştırmanın Modeli}

Araştırmada karma yöntem kullanılmıştır. Karma yöntem, nicel ve nitel verilerin toplandığ1, bu iki veri setinin birbiriyle bütünleştirildiği ve sonradan da bu iki veri setinden sonuçlar çıkarıldığı araştırma yaklaşımı olarak tanımlanır (Creswell, 2017: 2). Araştırmada hem nicel ve hem de nitel veriler toplanıp elde edilen veriler beraber yorumlandığından karma yöntem desenlerinden birleştirme/çeşitleme (triangulation) deseni kullanılmıştır. Bu desenin amacı, nicel ve nitel verileri topladıktan hemen sonra analiz etmek, sonuçları kıyaslamak ve sonuçları birleştirmektir (Creswell, 2017: 6).

\section{Çalışma Grubu}

Araştırmanın çalışma grubunu, B1 seviyesinde eğitim gören yabancı uyruklu öğrenciler oluşturmuş̧ur. Araştırmada, bir deney ve bir de kontrol grubu bulunmaktadır. Deney ve kontrol grupları, Harran Üniversitesi bünyesindeki TÖMER'de öğrenim gören öğrencilerden seçilmiştir. Araştırmada, B1 seviyesindeki iki sınıf, yansız atamayla deney ve kontrol grubu olarak belirlenmiştir. Araştırma, deney grubunda 21, kontrol grubunda 19, toplamda ise 40 öğrenci ile gerçekleştirilmiştir. Uygulama sürecinde, deney grubuna ders kitabındaki yazma çalışmaları dijital hikâye anlatımına dayalı yapılırken; kontrol grubuna ise yazma çalışmaları ders kitabındaki etkinliklere dayalı sürdürülmüştür.

\section{Veri Toplama Araçları}

Araştırmada nicel veriler, öğrencilerin kompozisyon çalışmalarından, "Yazılı Anlatım Dereceli Puanlama Anahtarı"ndan ve "Yazma Becerisi Öz Yeterlik Ölçeği”nden toplanırken nitel veriler ise "Yarı Yapılandırılmış Görüşme Formu"dan toplanmıştır.

\section{Kompozisyon Çalışmaları}

Araştırmada, yaratıcı yazma becerilerini ölçmek için deney ve kontrol grubuna ön-test ve son-test olarak kompozisyon yazma çalışmaları yaptırılmıştır. Öğrencilerden kompozisyon konusu olarak göç hikâyelerini, yani Türkiye'ye gelirken yaşadığı süreçleri hikâye tarzında anlatmaları istenmiştir. Bu amaçla, yabanc1 uyruklu öğrencilerden kendilerini özgür bir şekilde ifade etmeleri sağlanmıştır. Öğrencilerin ön-test ve son-test olarak yazdığı kompozisyon çalışmaları ölçmeye tabi tutulmuştur. $\mathrm{Bu}$ bağlamda öğrencilerin yazdığı kompozisyon çalışması, alanında iki uzman tarafından yazılı anlatım dereceli puanlama anahtarı (Büyükikiz, 2011) kullanılarak değerlendirilmiştir. 


\section{Yazılı Anlatım Dereceli Puanlama Anahtarı (Rubrik)}

Araştırmada öğrencilerin ön-test ve son-testte yazdıkları kompozisyon çalışmalarını değerlendirmek amacıyla Büyükikiz (2011) tarafından geliştirilen yazılı anlatım dereceli puanlama anahtarı kullanılmıştır. Kullanılan bu rubrikte, beş boyut ve bu boyutlara bağlı olarak on yedi alt boyut yer almaktadır. Rubrikte bulunan beş boyut: "Sayfa Düzeni, Başlık, Plan ve İsleyiş, Dil ve Anlatım, Yazım ve Noktalama" adı altında sıralanmıştır. Rubriğin puanlanma sistemi "1 puan (çok kötü), 2 puan (kötü), 3 puan (iyi), 4 puan (çok iyi)" şeklinde tanımlanmıştır. Buna bağlı olarak rubrikten alınabilecek en düşük puan 17 iken en yüksek puan ise 68 olarak hesaplanmıştır. Bu rubrik çoğunluğu farklı ülkelerin mensubu 50 yabancı uyruklu öğrenci üzerinde denenerek geliştirilmiştir.

Araştırma için kullanılan bu rubrik, B1 seviyesinde yer alan 40 öğrencin kompozisyon çalışmalarını incelemek için ön-test olarak uygulanmış ve ön-testten elde edilen veriler, SPSS 23 programında analiz edilerek, rubriğin Cronbach Alfa güvenirlik katsayısı 0,91 olarak hesaplanmıştır. Ayrıca araştırmada güvenirliğin arttırılması için öğrencilerin kompozisyon çalışmaları iki uzman tarafından değerlendirilmiştir. Puanlayıcılar arasındaki güvenirliği hesaplamak için SPSS 23 programı kullanılarak Cohen Cappa katsayısı hesaplanarak 0.65 olarak bulunmuştur.

\section{Yazma Öz Yeterlik Ölçeği}

Araştırmada, öğrencilerin yazma öz yeterliklerini incelemek için Büyükikiz (2011) tarafından geliştirilen ve 16 maddeden oluşan yazma öz yeterlik ölçeği kullanılmıştır. Ölçek, C2 seviyesinde olan 156 öğrenciye uygulanmıştır. 7’li likert modeliyle düzenlenen bu ölçekte bulunan olumlu ifadeler için "Katılmıyorum" 1, "Katılıyorum" 7 şeklinde derecelenirmiş; olumsuz ifadeler için ise "Katılmıyorum" 7, "Katıllyorum" 1 şeklinde derecelenmiştir. Öğrencilerin birinci faktörden alabilecekleri en yüksek puan 91; en düşük puan 13 olarak; ikinci faktörden alınabilecek en yüksek puan 21, en düşük puan ise 3 olarak hesaplanmıştır. Bu durumda ölçekten alınabilecek en yüksek toplam puan 112, en düşük toplam puan ise 16 olarak hesaplanmıştır. Ölçeğin açımlayıcı faktör analizi sonucunda, $\mathrm{KMO}=0,884$, Bartlett= 4334.683 değerlerine; doğrulayıcı faktör analizi sonucunda ise RMSEA $=0.048, \mathrm{AGFI}=0.86, \mathrm{SRMR}=.047, \mathrm{CFI}=0.99, \mathrm{NFI}=0.96, \mathrm{GFI}=0.90$ değerlerine ulaşılmıştır. Ölçeğin güvenirliğini ve iç tutarlılığını anlamak için Cronbach Alfa değeri hesaplanarak 0.92 olarak bulunmuştur.

Araştırma için kullanılacak olan yazma öz yeterlik ölçeği, ön-test olarak B1 düzeyinde olan 40 öğrenciye uygulanmış ve bunun sonucunda elde edilen veriler, SPSS 23 programında analiz edilerek ölçeğin Cronbach Alfa güvenirlik katsayısı 0.96 olarak hesaplanmıştır.

\section{Yarı Yapılandırılmış Görüşme Formu}

Araştırmanın nitel verilerin toplanması amacıyla yarı yapılandırılmış bir görüşme formu araştırmacı tarafından hazırlanmıştır. Görüşme formu, ölçme ve değerlendirme uzmanı ile Türkçe eğitimi uzmanın görüşlerine sunularak önerileri alınmış ve görüşme formunun son şekline karar verilmiştir. Yarı yapılandırılmış görüşme formuyla araştırmanın hem nicel verilerini desteklemek hem de araştırmanın derinliğini arttırmak amaçlanmıştır. Uygulama sonunda yarı yapılandırılmış görüşme formu altında öğrencilerin uygulama süreci hakkında görüşlerini almak için öğrencilere açık uçlu sorular sorulmuştur. 


\section{Verilerin Analizi}

\section{Nicel Verilerin Analizi}

Araştırmanın ön-test ve son-testinde deney ve kontrol grubu öğrencilerinin kompozisyon çalışmaları yazılı anlatım rubriğiyle değerlendirilmiş ve öğrencilere yazma öz yeterlik ölçeği uygulanıp elde edilen veriler analiz edilmiştir.

Araştırmada kullanılan yazılı anlatım rubriği non-parametrik istatistiksel yöntemlerden Mann-Whitney U testi kullanılarak deney ve kontrol grubunun ön-test ve son-testten aldıkları puanlarında anlamlı bir farklılık olup olmadığına bakılmıştır. Araştırmada, Mann-Whitney U testi, normallik varsayımını sağlamadığı için kullanılmıştır.

Öğrencilerin yazdığı kompozisyon çalışmaları, iki uzman tarafından yazılı anlatım rubriği kullanılarak değerlendirilmiştir. Puanlayıcılar arasındaki güvenirliği tespit etmek amacıyla SPSS 23 programı aracılığıyla Cohen Cappa katsayısı hesaplanarak sonuç, ön-testte 0.65 ; son-testte ise 0.63 olarak bulunmuştur. Bu sonuç 0.61 'den büyük olduğu için kodlayıcılar arasındaki uyum gücünün yükssek olduğunu gösterir (Landis \& Koch, 1977 akt. Bıkmaz-Bilgen \& Doğan, 2017).

Araştırmada, öğrencilerin yazma öz yeterlik ölçeğinden aldıkları ön-test ve son-test puanlarını kıyaslamak için bağımsız gruplar için t testi varsayımlarına bakılmıştır. Bu bağlamda her iki grubun ön ve son-testten aldıkları puanların çarpıklık ve basıklık katsayısına; aynı zamanda, varyanslarının eşit olup olmadığını test etmek için Levene testi sonuçlarına bakılmıştır. Bu sonuçlardan hareketle deney ve kontrol gruplarının Levene testi, ön-test ve son-test puanlarının varyansları eşit olduğu görülmüş̧ür.

\section{Nitel Verilerin Analizi}

Araştırmanın nitel veri analizi, yarı yapılandırılmış görüşme formundan elde edilen verilere dayalı yapılmıştır. Araştırmanın nitel verileri analiz edilirken içerik analizi kullanılmıştır. İçerik analizindeki esas amaç, toplanan verileri açıklamaya destek olacak kavramlara ve ilişkilere ulaşmaktır. İçerik analizinde görüşme, gözlem veya dokümanlar aracıllğıyla elde edilen nitel veriler: verilerin kodlanması, temaların bulunması, kod ve temaların düzenlenmesi, bulguların tanımlanması ve yorumlanması şeklinde dört aşamada analiz edilmektedir (Yıldırım \& Şimşek, 2006).

Nitel verilerin içerik analizinde, öncelikle öğrencilerle görüşme yapılmış ve öğrencilerin sorulara verdiği cevaplar alanla ilgili iki uzman tarafindan incelenerek kodlar tespit edilmiş ve bu kodlardan da temalar ortaya çıkarılmıştır. Kodlayıcılar arasındaki güvenirlik, Miles ve Huberman'ın (1994) formülüyle hesaplanarak güvenirlik katsayısı 0.93 olarak bulunmuştur. Saban'a (2009) göre nitel çalışmalarda kodlayıcılar arasındaki uyumun $\% 90$ ve üzeri olması çalışmanın güvenilir olduğunu anlamına gelmektedir.

\section{Bulgular}

\section{Nicel Bulgulara İlişkin Bulgular}

$\mathrm{Bu}$ bölümde araştırmanın nicel boyutuna ait öğrencilerin kompozisyon çalışmalarının değerlendirilmesinde kullanılan yazılı anlatım dereceli puanlama anahtarı ve yazma öz yeterlik ölçeği ön-test ve son-test puanlarıyla ilgili bulgulara ve yorumlara yer verilmiştir.

\section{Yazılı Anlatım Dereceli Puanlama Anahtarı (Rubriği) Ön-test ve Son-test Puanlarına İlişkin Bulgular ve Yorumlar}

Deney grubu ile kontrol grubunun yazılı anlatım rubriğinden aldıkları ön-test ve son-test puanları arasında anlamlı bir farklıı̆ı̆ın olup olmadığına bakılmıştır. Ayrıca her iki grubun yazılı anlatım rubriğinin boyutlarından aldıkları ön-test puanlarının (ortalaması, standart sapması, çarpıklık ve basıklık değerleri) betimsel istatistiğine bakılmıştır. 
Yapılan Mann-Whitney U testinin sonucuna göre, deney ve kontrol gruplarının yazılı anlatım rubriği ön-test puanları arasında anlamlı bir farklılık gözlenmemiştir [U=147, $(p=.159, p<0.05)]$. Öğrencilerin yazılı anlatım rubriğinden aldıkları Mann-Whitney $U$ testi ön-test puanlarına ait sonuçlar Tablo 1'de gösterilmiştir.

Tablo 1. Deney ve Kontrol Gruplarının Yazılı Anlatım Dereceli Puanlama Anahtarı Ön Test Ortalamaları Mann-Whitney U Testi Sonuçları

\begin{tabular}{llcccc}
\hline Gruplar & N & $\begin{array}{c}\text { Sira } \\
\text { Ortalamasi }\end{array}$ & $\begin{array}{c}\text { Sira } \\
\text { Toplam }\end{array}$ & U & $\boldsymbol{p}$ \\
\hline Deney & 21 & 18.02 & 378 & 147 & 0.159 \\
Kontrol & 19 & 23.24 & 441 & & \\
\hline
\end{tabular}

Tablo 1 incelendiğinde, her iki grubun arasında anlamlı bir farklılık olmadığ $1(p=0.159$, $p>0.05$ ) tespit edilmiştir. Bu sonuçlardan hareketle yazılı anlatım rubriği ön testine göre her iki grubunun yazılı anlatım seviyelerinin birbirine yakın olduğu sonucu ortaya çıkmaktadır.

Deney ve kontrol grubu öğrencilerinin yazılı anlatım rubriğinin boyutlarından alınan ön-test puanlarının betimsel istatistiği Tablo 2 ve Tablo 3 'te yer almaktadır.

Tablo 2. Deney ve Kontrol Grubu Öğrencilerinin Yazılı Anlatım Dereceli Puanlama Anahtarı'nın Boyutlarına Göre Ön-test Puanlarının Ortalaması ve Standart Sapması

\begin{tabular}{|c|c|c|c|c|}
\hline \multirow[b]{2}{*}{ Boyutlar } & \multicolumn{2}{|c|}{$\begin{array}{c}\text { Ön-test } \\
\text { Ortalama }\end{array}$} & \multicolumn{2}{|c|}{$\begin{array}{c}\text { Ön-test } \\
\text { Sd (Standart Sapma) }\end{array}$} \\
\hline & Deney & Kontrol & Deney & Kontrol \\
\hline Sayfa Düzeni & 6.42 & 6.89 & 1.93 & 1.41 \\
\hline Başlık & 1.14 & 1.00 & 0.65 & 0.474 \\
\hline Plan ve İşleyiş & 13.86 & 14.11 & 3.41 & 3.69 \\
\hline Dil ve Anlatım & 11.05 & 12.42 & 2.17 & 2.63 \\
\hline Yazım ve Noktalama & 3.86 & 4.63 & 1.06 & 0.89 \\
\hline
\end{tabular}

Tablo 2'ye göre her iki grubunun yazılı anlatım rubriği boyutlarından aldıkları ön-test puan ortalamalarının birbirine yakın olduğu gözlemlenmektedir.

Tablo 3. Deney ve Kontrol Grubu Öğrencilerinin Yazılı Anlatım Dereceli Puanlama Anahtarı'nın Boyutlarına Göre Ön-test Puanlarının Çarpıklık ve Basıklık Değerleri

\begin{tabular}{llccc}
\hline & \multicolumn{2}{c}{$\begin{array}{c}\text { Ön-test } \\
\text { Çarpıklık }\end{array}$} & \multicolumn{2}{c}{$\begin{array}{c}\text { Ön-test } \\
\text { Basıklık }\end{array}$} \\
\cline { 2 - 5 } Boyutlar & Deney & Kontrol & Deney & Kontrol \\
\hline Sayfa Düzeni & 0.233 & -0.458 & -0.682 & -0.493 \\
\hline Başlık & $\mathbf{4 . 5 8}$ & $\mathbf{6 . 3 2 5}$ & $\mathbf{2 1 . 0 0}$ & $\mathbf{4 0 . 0 0}$ \\
\hline Plan ve İşleyiş & 0.319 & -0.278 & -0.966 & 0.615 \\
\hline Dil ve Anlatım & 0.414 & 0.672 & 0.504 & 0.893 \\
\hline Yazım ve Noktalama & 0.537 & 0.337 & $\mathbf{3 . 6 7}$ & -0.836 \\
\hline
\end{tabular}

Tablo 3 bakıldığında ise rubrik boyutlarından alınan puanların çarpıklık ve basıklık değerlerinin normal dağılım gösterdiği görülmektedir. Ancak başlık boyutunda her iki grubun çarpıklık ve basıklık değerlerinin normal dağılım göstermediği görülmektedir. Ayrıca yazım ve noktalama boyutunda deney grubunun basıklık değerinin normal dağılım göstermediği tespit edilmiştir. 
Yapılan Mann-Whitney U testinin sonuçlarına göre, deney ve kontrol gruplarının yazılı anlatım rubriği son-test puanları arasında deney grubu lehine anlamlı bir farklılık bulunmuştur [U= 63.50, $(p=.000, p<0.05)]$. Her iki grubun yazılı anlatım rubriğinden aldıkları son-test puanlarına ilişkin Mann-Whitney U testi sonuçları Tablo 4'te verilmiştir.

Tablo 4. Deney ve Kontrol Gruplarının Yazılı Anlatım Dereceli Puanlama Anahtarı Sontest Ortalamaları Mann-Whitney U Testi Sonuçları

\begin{tabular}{lccccc}
\hline Gruplar & N & $\begin{array}{c}\text { Sira } \\
\text { Ortalaması }\end{array}$ & $\begin{array}{c}\text { Sira } \\
\text { Toplam }\end{array}$ & U & $\boldsymbol{p}$ \\
\hline Deney & 21 & 28.17 & 566.50 & 63.50 & 0.000 \\
Kontrol & 19 & 12.03 & 253.50 & & \\
\hline
\end{tabular}

Tablo 4'e göre deney ve kontrol grupları arasında anlamlı bir farklılık olduğu $(p=.00, p<0.05)$ görülmektedir. $\mathrm{Bu}$ sonuçlardan hareketle dijital hikâye anlatımının öğrencilerin yazılı anlatım becerisini geliştirdiği sonucu ortaya çıkmaktadır.

Deney ve kontrol grubunun yazılı anlatım rubriğinin boyutlarından aldıkları son-test puanlarının betimsel istatistiği Tablo 5 ve Tablo 6'da verilmiştir.

Tablo 5. Deney ve Kontrol Grubu Öğrencilerinin Yazılı Anlatım Dereceli Puanlama Anahtarı'nın Boyutlarına Göre Son-test Puanlarının Ortalaması ve Standart Sapması

\begin{tabular}{lcccc}
\hline \multirow{2}{*}{ Boyutlar } & \multicolumn{2}{c}{$\begin{array}{c}\text { Son-test } \\
\text { Ortalama }\end{array}$} & \multicolumn{2}{c}{$\begin{array}{c}\text { Son-test } \\
\text { Sd (Standart Sapma) }\end{array}$} \\
\cline { 2 - 5 } & Deney & Kontrol & Deney & Kontrol \\
\hline Sayfa Düzeni & 10.29 & 8.11 & 1.58 & 1.44 \\
\hline Başlık & 2.43 & 1.37 & 1.32 & 0.83 \\
\hline Plan ve İșleyiş̧ & 20.90 & 16.89 & 2.56 & 2.94 \\
\hline Dil ve Anlatım & 17.10 & 13.37 & 2.23 & 2.03 \\
\hline Yazım ve Noktalama & 3.86 & 4.63 & 1.06 & 0.89 \\
\hline
\end{tabular}

Tablo 5 'te deney ve kontrol grubunun yazılı anlatım rubriğin boyutlarına göre aldıkları puan ortalamalarının deney grubunda artış olduğu görülmektedir. Buna göre Tablo 6'da yer alan veriler, yapılan Mann Whitney U test sonuçlarını doğrulamaktadır.

Tablo 6. Deney ve Kontrol Grubu Öğrencilerinin Yazılı Anlatım Dereceli Puanlama Anahtarı'nın Boyutlarına Göre Son-test Puanlarının Çarpıklık ve Basıklık Değerleri

\begin{tabular}{lcccc}
\hline \multirow{2}{*}{ Boyutlar } & \multicolumn{2}{c}{$\begin{array}{c}\text { Son-test } \\
\text { Çarpıklık }\end{array}$} & \multicolumn{2}{c}{$\begin{array}{c}\text { Son-test } \\
\text { Basıklık }\end{array}$} \\
\cline { 2 - 5 } & Deney & Kontrol & Deney & Kontrol \\
\hline Sayfa Düzeni & -0.438 & -0.081 & -0.909 & 0.250 \\
\hline Başlik & -0.044 & 2.418 & -1.874 & $\mathbf{5 . 4 9 5}$ \\
\hline Plan ve İşleyiş & -0.60 & 0.115 & -1.590 & 1.472 \\
\hline Dil ve Anlatım & 0.017 & 0.279 & -1.336 & 0.224 \\
\hline Yazım ve Noktalama & -0.010 & 0.339 & -0.092 & -1.749 \\
\hline & & & &
\end{tabular}

Tablo 6'ya göre yazılı anlatım rubriğinin boyutlarından alınan puanların çarpıklık ve basıklık değerlerine bakıldığında genel olarak normal dağılım göstermektedir. Ancak kontrol grubunun başlık boyutundan aldığı basıklık değerinin normal dağılım göstermediği tespit edilmiştir. 


\section{Yazma Öz Yeterlik Ölçeği Ön-test ve Son-test Puanlarına İlişkin Bulgular ve Yorumlar}

Deney grubu ile kontrol grubunun "Yazma Öz Yeterlik Ölçeği”nden aldıkları ön-test ve sontest puanları arasında anlamlı bir farklılığın olup olmadığına bakılmıştır. Her iki grubun yazma öz yeterliğine ilişkin ön-test puanlarının normallik değerini belirten çarpıklık ve basıklık değerleri Tablo 7'de gösterilmiştir.

Tablo 7. Deney ve Kontrol Gruplarının Yazma Öz Yeterlik Ölçeği Ön-test Çarpıklık ve Basıklık Değerleri Tablosu

\begin{tabular}{lcc}
\hline Gruplar & Çarpıklık (Skewness) & Basıklık (Kurtosis) \\
\hline Deney & -0.348 & 0.514 \\
Kontrol & -0.494 & -0.609 \\
\hline
\end{tabular}

Tablo 7 incelendiğinde her iki grubun çarpıklık ve basıklık değerlerinin -2 ile +2 arasında olması, grupların aldığı puanların normal bir dağılım gösterdiği görülmektedir. Ayrıca Levene testi sonucuna göre, $(p=0.753, p>0.05)$ gruplar aras1 varyansin homojen olduğu görülmektedir. Buna göre her bir verinin diğerinden bağımsız olduğu anlaşılmaktadır. Bu bulgular, t-testinin varsayımlarının sağlandığını göstermektedir.

Yapılan ilişkisiz gruplar için t-testinde, deney grubu yazma öz yeterlik ölçeği ön-test puan ortalaması $(\overline{\mathrm{X}}=73.52)$ ile kontrol grubu yazma öz yeterlik ölçeği ön-test puan ortalaması $(\overline{\mathrm{X}}=79.31)$ arasında anlamlı bir farklılık görülmemiştir $\left.\left[t_{(38)}=1.084, p=.285, p<0.05\right)\right]$. Buna göre her iki grubun yazma öz yeterlik ölçeği ön-test ortalamaları t-testi sonuçları Tablo 8'de verilmiştir.

Tablo 8. Deney ve Kontrol Gruplarının Yazma Öz Yeterlik Ölçeği Ön-test Ortalamaları tTesti Sonuçları

\begin{tabular}{llccccc}
\hline Gruplar & $\mathbf{N}$ & $\overline{\boldsymbol{X}}$ & $\boldsymbol{S d}$ & $\boldsymbol{d} \boldsymbol{f}$ & $\boldsymbol{t}$ & $\boldsymbol{p}$ \\
\hline Deney & 21 & 73.52 & 17.01 & 38 & 1.084 & 0.285 \\
Kontrol & 19 & 79.31 & 16.71 & & & \\
\hline
\end{tabular}

Tablo 8 incelendiğinde her iki grubun aldıkları puanlar arasında anlamlı bir farklılık olmadığı görülmektedir. Yani yazma öz yeterlik ölçeği ön-testine göre her iki grubunun yazma öz yeterlik düzeylerinin birbirine yakın olduğu sonucu ortaya çıkmıştır.

Deney ve kontrol gruplarının yazma öz yeterliğine ilişkin son-test puanlarının normallik değerlerini gösteren çarpıklık ve basıklık değerleri Tablo 9'da gösterilmiştir.

Tablo 9. Deney ve Kontrol Gruplarının YÖYÖ Son-test Çarpıklık ve Basıklık Değerleri

Tablosu

\begin{tabular}{lcc}
\hline Gruplar & Çarpıklık (Skewness) & Basıklık (Kurtosis) \\
\hline Deney & -0.271 & -0.377 \\
Kontrol & 0.81 & -1.279 \\
\hline
\end{tabular}

Tablo 9'a göre her iki grubun çarpıklık ve basıklık değerlerinin -2 ile +2 arasında olması, normal bir dağılımda olduğunu göstermektedir. Aynı zamanda, Levene testi sonucuna göre ( $p=$ $0.338, p>0.05$ ) gruplar arası varyansın homojen olduğu tespit edilmiştir. Her bir verinin diğerinden bağımsız olduğu görülmektedir. Bu bulgular, t-testinin varsayımlarının sağlandığını göstermektedir. 
Yapılan ilişkisiz gruplar için t-testinde, deney grubunun yazma öz yeterlik ölçeği son-test puan ortalaması $(\overline{\mathrm{X}}=87.24)$ ile kontrol grubunun yazma öz yeterlik ölçeği son-test puan ortalamas1 $(\overline{\mathrm{X}}=78,26)$ arasında anlamlı bir farklılık görülmektedir $\left[t_{(38)}=2.042, p<0.05,(p=.048, p<0.05)\right]$.

Deney ve kontrol gruplarının yazma öz yeterlik ölçeği son-test ortalamaları t-testi sonuçları Tablo 10'da verilmiştir.

Tablo 10. Deney ve Kontrol Gruplarının Yazma Öz Yeterlik Ölçeği Son-test Ortalamaları t-Testi Sonuçları

\begin{tabular}{lcccccc}
\hline Gruplar & $\mathbf{N}$ & $\overline{\mathbf{X}}$ & $\boldsymbol{s} \boldsymbol{d}$ & $\boldsymbol{d} \boldsymbol{f}$ & $\boldsymbol{t}$ & $\boldsymbol{P}$ \\
\hline Deney & 21 & 87.24 & 13.21 & 38 & 2.042 & 0.048 \\
Kontrol & 19 & 78.26 & 14.58 & & & \\
\hline
\end{tabular}

Tablo 10'a göre deney ve kontrol grupları arasında anlamlı bir farklılık olduğu görülmektedir. Bu sonuçlardan hareketle yazma öz yeterlik düzeylerinde deney grubunun lehine istatistiksel olarak anlamlı bir farklılık olduğu ortaya çıkmıştır.

Deney ve kontrol grubunun öz-yeterlik ölçeğinden aldıkları son-test puanları arasındaki farkın etki büyüklüğü $d=0.64$, etki boyutu ise $r=0.30$ olarak hesaplanmıştır. Green ve Salkind'e göre (2005) gruplar arasındaki etki büyülüğü farkının orta düzeyde olduğunu göstermektedir.

\section{Araştırmanın Nitel Bulguları}

Araştırmanın nitel bulguları analizinde içerik analizi yönteminden yararlanılmıştır. Dijital hikâyelerle yaratıcı yazma çalışmaları yapan deney grubu öğrencilerinin görüşlerinden nitel veriler elde edilerek değerlendirmeler yapılmıştır. Öğrencilerle yapılmış görüşmelerde: "Dijital hikâyelerle yazma becerinizin geliştiğine inanıyor musunuz?" sorusuna yönelik öğrencilerin yazma becerisi ve yazma öz yeterliklerine ilişkin görüşleri alınmış ve elde edilen sonuçlar nitel olarak değerlendirilmiştir.

Öğrencilerin yazma becerisi ve yazma öz yeterliği hakkındaki bazı görüşleri şunlardır:

Önce yazmada çalışma yaptiğimiz için yazmam gelişsti. Eee.. ses kaydına aldık. Ses kaydl yaparken kunuşmamız da gelişti $\mathbf{0 ̈ 1 5}(\boldsymbol{E})$.

Inl. bence dijital hıkaye benim yazmamı ilerledi. Arttı yazmam. Sunra okuduk biz hıkayelerimizi bunun için okumam da gilisşti. Telfon kullanmamız daha iyi oldu Ö13(E).

Yazma çalışmaları yaptık, ekleri ve kelimeleri doğru yazlyordum. Her şeyi düzgün yazamıyordum, ekleri düzgün şekilde kuramıyordum. Ancak yazma çalışmaları yaptık, ekleri ve kelimeleri doğru yazlyorum $\mathbf{0} \mathbf{4}(\boldsymbol{K})$.

Bazı kilime kullanımım iyi değil yanliş̧ti, düzeltim. Eee başka başka bağlaç öğrendim Ö7(E).

Ben büyük harfler yanliş kullanırdım. Eee ancak ben şimdi az hata yaparım Ö9(E).

Eee.. ek öğrendik. Yani çok şiyi öğrendik yazmam giliş̧ti Ö10(K).

Çalışmalar yaptik. Daha kulay yazı yazabiliyorum. Noktalama öğrendik. Itı.. kural ögrendik $\mathbf{0 ̈ 6}(\mathbf{K})$.

In cümlelerim eksikti. Cümleler çallştık (...) Cümleleri daha düzgün kurabiliyorum artik. Sunra hucamız bize giriş, giliş̧me, sunuç paragrafinı anlatti. Daha önce bilmiyordum. Artik biliyorum. Yazmam gilişti Ö3(E).

Yazmaya başlamadan konuyu kafamda düşündüm. Giriş, gelişme ve sonucu öğrendim Ö14(K).

Yazı yazarken dikkat iderim ve sayfa düzenine dikkat iderim $\mathbf{O ̈}(\boldsymbol{E})$.

Sinaryo yazarken başlık kullanmayı ögretti Ö7(E).

Yukarıdaki bulgulardan hareketle öğrencilerin dijital hikâyelere dayalı olarak yazım ve noktalama, dil bilgisi, kelime, cümle ve paragraf çalışmaları; sayfa düzeni ve başlık çalışmaları 
yaptığı görülmektedir. Buna göre öğrencilerle yapılan dijital hikâye anlatımına dayalı yazma çalışmaları ve etkinlikleri öğrencilerin yazma becerisi üzerinde etkili olduğu sonucunu ortaya çıkarmaktadır. Özellikle öğrencilerin uygulamadan önce noktalama işaretleri ve yazım ile ilgili kurallarda sıkıntı yaşadıklarını, uygulamadan sonra bu sıkıntıları düzelttiklerini; eklerin kullanımını önceki derslere nazaran daha iyi öğrendiklerini; çok daha fazla kelime öğrendiklerini ifade etmeleri öğrencilerin yazma becerisinin uygulama öncesine göre daha iyi olduğunun sonucunu çıkarmıştır.

\section{Sonuç ve Tartışma}

Uygulamanın başında yapılan ön-test sonuçlarına göre, deney grubu ile kontrol grubunun arasında, yazılı anlatım rubriğinden $[\mathrm{U}=147,(p=.159, p<0.05)]$ ve yazma öz-yeterlik ölçeğinden $[t$ $\left.\left.{ }_{(38)}=1.084, p=.285, p<0.05\right)\right]$ aldıkları puanlara göre anlamlı bir farklılık görülmemiştir.

Uygulamanın sonunda yapılan son-test sonuçlarına göre deney grubu ile kontrol grubunun arasında, yazılı anlatım rubriğinden $[\mathrm{U}=63.50,(p=.000, p<0.05)]$ ve yazma öz-yeterlik ölçeğinden $\left[t_{(38)}=2.042,(p=.048, p<0.05)\right]$ aldıkları puanlara göre deney grubu lehine anlamlı bir farkl111k görülmüştür. Bu göre dijital hikâye anlatımının yabancı dilde Türkçe öğrenen öğrencilerin yaratıcı yazma becerilerini geliştirmede ve yazma öz-yeterlikleri üzerinde mevcut programdan daha etkili olduğu sonucu ortaya çıkmıştır.

Yabanc1 dil olarak Türkçe öğrenen öğrencilerin yazma becerilerini ve yazma özyeterliklerini geliştirmeye yönelik çalışmalarla yapılan araştırma bulgularında benzerlikler olduğu görülmektedir. Bu bakımdan, Turkben (2019) çalışmasında, öğrencilere uygulanan yaratıcı yazma çalışmalarının öğrencilerin yazma becerisi ile yazma öz yeterliğinin üzerinde etkili olduğunun sonucuna ulaşmıştır. Aşçı (2019) çalışmasında B2 seviyesinde yer alan yabancı uyruklu öğrencilerin öykü yazma çalışmalarını kullandıktan sonra yazma becerilerinin geliştiğini tespit etmiştir. Yıldırım (2018) yabanc1 dil olarak Türkçe öğrenen B2 seviyesindeki deney grubu öğrencilerinin yazma gelişim dosyası uygulamasını kullandıktan sonra yazma becerisinin geliştiği sonucuna ulaşmıştır. Büyükikiz (2011) çalışmasında C1 seviyesinde bulunan öğrencilerin yazma öz yeterlikleri ile yazılı anlatım becerileri arasında pozitif bir ilişki olduğunu tespit etmiştir. Ayrıca okuma sıklığı ile yapılan yazma çalışmalarının öğrencilerin yazma öz yeterliklerine olumlu etkiler sağladığını ifade etmiştir.

Yabancı dil öğretiminde dijital hikâye anlatımıyla yazma becerisini geliştirmeye dönük çalışmaların bulgularıyla yapılan çalışmanın bulguları birbiriyle benzerlik göstermektedir. Kim (2018) çalışmasında, lisans öğrencilerinin dijital hikâye anlatımı yoluyla yazma yeteneklerinin geliştiğini ifade etmiştir. Balaman Uçar (2016) İngilizce öğrenen lisans öğrencilerinin dijital hikâyelere dayalı bütünleşik yazma çalışmaları yaptıktan sonra yazma becerileri ve yazma öz yeterliklerinde deney grubu lehine anlamlı sonuçlar tespit etmiştir. Abdel-hack ve Helwa (2014) lisans öğrencileriyle yaptığı çalışmasında, dijital hikâye anlatımıyla ders işleyen deney grubunun anlatı yazma becerisinin kontrol grubuna göre daha başarılı olduğunu tespit etmiştir. Sepp ve BandiRao (2015), dijital hikâye anlatımıyla ders işleyen deney grubu öğrencilerin yazma becerisinin geliştiğini ifade etmiştir.

Sonuç olarak farklı yaş ve okul düzeyinde bulunan öğrencilerin dijital hikâye anlatımıyla yazma yetkinliği, yazma öz yeterliği ve yazma performansının arttığı söylenebilir. Aynı zamanda yapılan çalışmaların yazma becerisi ile yazma öz yeterliği arasında pozitif anlamda bir ilişkinin olduğu sonucu da ortaya çıkmaktadır. Bu bakımdan araştırmadan elde edilen sonuçlarla ve yapılan çalışmaların sonuçları birbirini desteklemektedir.

Araştırmanın nitel sonuçlarına bakıldığında, görüşme yapılan öğrenciler, dijital hikâye anlatımıyla kompozisyon yazma becerilerinin geliştiğini; senaryo yazarken imla ve noktalamayla ilgili bilgiler öğrendiklerini; kelime, cümle ve paragraf gibi yazma çalışmaları ve etkinlikleri yaptıklarını ifade etmiştir. Ayrıca öğrenciler, uygulama öncesinde noktalama işaretleri ve yazım 
kurallarıyla ilgili sorunlarının olduğunu, uygulama sonunda ise bu bilgileri daha iyi öğrendiklerini ve bu şekilde yazma becerilerinin geliştiğini, daha fazla kelime öğrendiklerini ifade etmiştir.

Dijital hikâyelerin yazma becerisine katkısını inceleyen çalışmalardan elde edilen nitel sonuçlarla araştırmadan elde edilen nitel sonuçlar birbirini desteklemektedir. Buna göre, Balaman Uçar (2016) çalışmasında, İngilizce öğrenen öğrenciler, dijital hikâye çalışması yaptıktan sonra dilbilgisi, imla veya kelime bilgisi gibi alt yazma becerilerinin geliştiğini ifade etmiştir. Kim (2018) çalışmasında öğrenciler, dijital hikâyeler uygulamasının senaryo oluşturmak ve hikâye yazmak için iyi bir firsat sağladığını, yazmalarında iyileşme olduğunu, yabancı dil öğrenme farkındalığının arttığını, kelimeleri yerinde ve doğru kullandığını ve yazdıklarını düzeltme olanağı sağladığını ifade etmiştir. Abdel-hack ve Helwa (2014) lisans öğrencileriyle yaptı̆̆ 1 çalışmada, öğrencilerin dijital hikâyelerle yazım ve noktalama bilgisi; kelime, cümle ve paragraf bilgisinin arttığını ve düzenleme becerilerinde gelişmeler olduğunu ortaya koymuştur.

Sonuç olarak yapılan çalışmalarda öğrencilerin görüşleri incelendiğinde, dijital hikâye anlatımının öğrencilerin yazma becerilerine ve yazma yeterliliklerine olumlu anlamda katkı sağladığı ifade edilebilir.

\section{Kaynakça}

Abdel-Hack, E. M. \& Helwa, H. S. A. H. A. (2014). Using digital storytelling and weblogs instruction to enhance EFL narrative writing and critical thinking skills among EFL majors at faculty of education. Educational Research, 5(1), 8-41.

Açık, F. (2008). Türkiye'de yabancılara Türkçe ögretilirken karşılaşılan sorunlar ve çözüm önerileri. Doğu Akdeniz Üniversitesi Eğitim Fakültesi Türkçe Eğitimi Bölümü, Uluslararası Türkçe Eğitimi ve Öğretimi Sempozyumu'nda sunulan bildiri.

Arslan, M. \& Klıcıc, E. (2015). Yabancı dil olarak Türkçe öğretiminde yazma becerisinin gelişiminde karşılaşılan sorunlar: Bosna Hersek örneği. Kırıkkale Üniversitesi Sosyal Bilimler Dergisi, 5 (2), 169-182.

Aşçı, Y. (2019). Yabancı dil olarak Türkçe öğretiminde öykü: B2 düzeyinde okuma ve yazma becerisi geliştirme [Yayımlanmamış doktora tezi]. Hacettepe Üniversitesi, Türkiyat Araştırmaları Enstitüsü.

Balaman Uçar, S. (2016). Dijital öykülemenin İngilizceyi yabancı dil olarak öğrenen ögrrencilerin yazma becerilerine olan etkisi. [Yayımlanmamış doktora tezi]. Hacettepe Üniversitesi, Eğitim Bilimleri Enstitüsü.

Barret, H.C. (2009). How to Create Simple Digital Stories. http://electronicportfolios.com/digistory/howto.html

Bilgen, Ö. B. \& Doğan, N. (2017). Puanlayıcılar arası güvenirlik belirleme tekniklerinin karşılaştırılması. The Comparison of Interrater Reliability Estimating Techniques. Journal of Measurement and Evaluation in Education and Psychology, 8(1), 63-78. https://doi.org/10.21031/epod.294847

Büyükikiz, K. K. (2011). Türkçeyi yabancı dil olarak öğrenenlerin yazma becerileri ile öz yeterlilik algıları arasındaki ilişki üzerine bir araştırma. [Yayımlanmamış doktora tezi]. Gazi Üniversitesi Eğitim Bilimleri Enstitüsü.

Ciğerci, F. M. \& Gultekin, M. (2017). Use of digital stories to develop listening comprehension skills. Issues in Educational Research, 27(2), 252-268. http://www.iier.org.au/iier27/cigerci.html 
Coşkun, E. (2014) Yazma eğitimi. (Editörler) A. Kırkkılıç ve H. Akyol. İlköğretimde Türkçe ögretimi. Dördüncü Bask1, Pegem A Yayınları, 49-91.

Creswell, J. W. (2017). Karma yöntem araştırmalarına giriş. (M. Sözbilir, Çev.), Pegem Akademi.

Çakır, İ. (2010). Yazma becerisinin kazanılması yabancı dilde neden zordur?. Sosyal Bilimler Enstitüsü Dergisi, 28, 165- 176

Diaw, P. W. (2009). Case study: the influence of storytelling as prewriting activity (in the writing process) on narrative writing in the child left behind learning environment. Unpublished doctoral dissertation, Saint Joseph's University.

Foley, L. M. (2013). Digital storytelling in primary-grade classrooms (Doctoral dissertation). Retrieved from ProQuest Dissertations \& Theses Global.

Frazel, M. (2010). Digital storytelling guide for educators. Washington, DC: International Societyfor Technology in Education.

Genç İlter, B. (2014). Yabancı dil öğretiminde yazma becerisi nasıl geliştirilebilir?. Dil Dergisi, (163), 36-45. https://doi.org/10.1501/dilder_0000000205

Genç, H. N. (2017). Yabancı dil olarak Türkçe öğretiminde yazma eğitimi bağlamında yazım ve noktalama. Dil Dergisi, 168 (2), 31-42. https://doi.org/10.1501/dilder_0000000242

Göçer, A. (2010). Türkçe öğretiminde yazma eğitimi. Uluslararası Sosyal Araştırmalar Dergisi, $3(12), 178-195$.

Green, M. R. (2011). Teaching the writing process through digital storytelling in pre-service education (Doctoral dissertation). Retrieved from ProQuest Dissertations \& Theses Global.

Green, S. \& Salkind, N. (2005). Using SPSS for Windows and Macintosh: Understanding and Analysing Data. Upper Saddle River, NJ: Prentice Hall.

Güneş, F. (2014) Yabancı dil olarak Türkçe yazma öğretimi: Yaklaşım ve modeller., (Editör) A. Şahin. Yabancı dil olarak Türkçe ögretimi (kuramlar, yaklaşımlar, etkinlikler). Birinci Bask1, Pegem A Yayınları, 337-361.

İnal, S. (2014) Yabancı dil olarak Türkçe yazma öğretimi: Yabancı dil olarak Türkçenin öğretiminde yazmanın önemi ve yazma etkinlikleri. (Editör) A. Şahin. Yabancı dil olarak Türkçe öğretimi (kuramlar, yaklaşımlar, etkinlikler). Birinci Bask1, Pegem A Yayınları, 362-372.

İşcan, A. (2011). Türkçenin yabancı dil olarak önemi. Uluslararası Avrasya Sosyal Bilimler Dergisi, 2(4), 29-36.

Jakes, D. S. \& Brennan, J. (2005). Capturing stories, capturing lives: An introduction to digital storytelling. Retrieved from http://www.jakesonline.org/dst_techforum. pdf

Karadağ, Ö. \& Maden, S. (2014). Yazma eğitimi: Kuram, uygulama, ölçme ve değerlendirme. (Editörler) A. Güzel ve H. Karatay. Türkçe ögrretimi el kitabı. İkinci Baskı, Pegem A Yayınlar1, 265-306. https://doi.org/10.14527/9786053645269.11

Kaya, M. \& Kardaş, M.N. (2019a). Türkçenin yabancı dil olarak öğretim programları -1 2016, 2017 Türkçe öğretim programları (MEB). M. N. Kardaş (Editör). Türkçenin yabancı dil olarak ögretimi içinde (s. 79-101), Pegem Akademi.

Kaya, M. \& Kardaş, M.N. (2019b). Türkçenin yabancı dil olarak öğretim programları -2 Türkiye Maarif Vakfının hazırladığı program (TMV, 2019). M. N. Kardaş (Editör). Türkçenin yabancı dil olarak öğretimi içinde (s. 103-131), Pegem Akademi. 
Kim, P. (2018). Implementing digital storytelling and students' writing ability development in an EFL college classroom. Multimedia-Assisted Language Learning, 21(1), 77-106.

Kulla-Abbott, T. M. (2006). Developing literacy practices through digital storytelling [Doctoral dissertation]. Retrieved from ProQuest Dissertations \& Theses Global.

Lambert, J. (2003). Digital storytelling cookbook and traveling companion. (Version 4.0). Digital Diner Press, Berkeley, CA.

Lambert, J. (2006). Digital storytelling cookbook (2nd ed.). Berkeley, CA: Digital Diner Press. Retrieved from http://redcrossyouth.org/wp-content/uploads/2012/03/cds-cookbook.pdf

MEB. (2009). Diller için Avrupa ortak başvuru metni ögrenme-öğretme-değerlendirme. http://www.dilbilimi.net/ab_diller_icin_ortak_avrupa_basvuru_metni_eb_pdf.

Melanlığlu, D. \& Atalay, T. D. (2016). Yabancı dil olarak Türkçe öğrenenlerin yazma öz yeterlikleri üzerinde yaratıcı yazma uygulamalarının etkisi. Türkiye Sosyal Araştırmalar Dergisi, 20(3), 697-721.

Ohler, J. (2006). The World of dijital storytelling, Edicational Leadership, 63(4), 44-47.

Robin, B. (2006) The educational uses of digital storytelling, Society for Information Technology and Teacher Education International Conference, 1, 709-716.

Robin, B. R. (2008). Digital storytelling: A powerful technology tool for the 21st century classroom. Theory Into Practice, 47(3), 220-228. https://doi.org/10.1080/00405840802153916

Saban, A. (2009). Öğretmen adaylarının öğrenci kavramına ilişkin sahip oldukları zihinsel imgeler, Türk Ë̆itim Bilimleri Dergisi, 7(2), 281-326.

Sepp, M. \& Bandi-Rao, S. (2015). Creating an effective model for digital storytelling in the ESL writing class, CUNY Academic Works.

Sever, T. (2014). An investigation into the impact of digital storytelling on the motivation level of students. Yayımlanmamış Yüksek Lisans Tezi, Çanakkale Onsekiz Mart Üniversitesi, Eğitim Bilimleri Enstitüsü.

Speaker, K. (2010). Speaking the lower frequencies 2.0: digital ghost stories. Mentoring literacy professionals: continuing the spirit of CRA/ALER after 50 years, 27, 28-33.

Tok, M. (2013). Yabancılara Türkçe öğretimi ders kitaplarındaki yazma çalışmalarının değerlendirilmesi. Uşak Sosyal Bilimler Dergisi. Sayı 6/1. https://doi.org/10.12780/uusbd147

Turgut, G. ve Kışla, T. (2015). Bilgisayar destekli hikâye anlatımı yöntemi: Alanyazın araştırması. Turkish Online Journal of Qualitative Inquiry, 6(2), 97-121. https://doi.org/10.17569/tojqi.57305

Turkben, T. (2019). The effects of creative writing practices on the writing skills of students learning Turkish as a second language. Eurasian Journal of Educational Research, 19(83), 183-208. https://doi.org/10.14689/ejer.2019.83.9

Ungan, S. (2007). Yazma becerisinin geliştirilmesi ve önemi. Sosyal Bilimler Enstitüsü Dergisi 23(2), 461-472.

Xu, Y., Park, H., \& Baek, Y. (2011). A new approach toward digital storytelling: An activity focused on writing self-efficacy in a virtual learning environment. Educational Technology \& Society, 14(4), 181-191. 
Yıldırım, A. \& Şimşek, H. (2006). Sosyal bilimlerde nitel araştırma yöntemleri. (6. baskı). Seçkin Yayıncilik.

Yıldırım, M. (2018). Yabancılara Türkçe öğretiminde yazma gelişim dosyası uygulaması [Yayımlanmamış doktora tezi]. Gazi Üniversitesi Eğitim Bilimleri Enstitüsü.

Y1lmaz, Y., Üstündağ, M. T. \& Güneş, E. (2017). Öğretim materyali olarak dijital hikâye geliştirme aşamalarının ve araçlarının incelenmesi. Abant İzzet Baysal Üniversitesi Eğitim Fakültesi Dergisi, 17(3), 1621-1640. https://doi.org/10.17240/aibuefd.2017.17.31178-338851 